\title{
DEVELOPMENT AND IMPLEMENTATION OF ELECTRONIC SERVICE FOR ENVIRONMENTAL IMPACT ASSESSMENT FROM PLANNED ROAD CONSTRUCTION ACTIVITIES
}

\author{
РОЗРОБКА ТА ВПРОВАДЖЕННЯ ЕЛЕКТРОННОГО \\ СЕРВІСУ $З$ ОЦІНКИ ВПЛИВУ НА ДОВКІЛЛЯ \\ ВІД ПЛАНОВАНОЇ ДІЯЛЬНОСТІ 3 БУДІВНИЦТВА ДОРІГ
}

\author{
Anna Kharchenko ${ }^{1}$ \\ Ylia Khrutba ${ }^{2}$
}

DOI: https://doi.org/10.30525/978-9934-26-021-6-40

Abstract. The main idea of the study was to automate the environmental impact assessment process. The subject of the research is the process of algorithmization and automation of environmental impact assessment. During the research, the methods of impact assessment as tools for analyzing the impact of road repair processes are considered in detail. And also the mathematical device which can be applied to an estimation of influence on environment of processes of construction and reconstruction of roads is algorithmized. The main aspects of the impact during the technological process of road repair, which formed the criterion basis for environmental impact assessment, are characterized and formed. The methodology of this study is based on the use of a combined approach to environmental impact assessment using the improved Leopold matrix and its further study using the Harrington function. At each stage of both the implementation of the stages of the environmental impact assessment and the processes themselves during the construction and reconstruction (repair) of the highway, the information can be presented in the form of different matrices. Based on the methodology and algorithm for quantifying the impact on the environment using the Leopold matrix and the Harrington desirability function, an electronic

\footnotetext{
${ }^{1}$ Candidate of Technical Sciences, Associate Professor,

Associate Professor of Transport Construction and Property Management Department,

National Transport University, Ukraine

${ }^{2}$ Candidate of Economic Sciences,

Associate Professor of the Department of Transport Law and Logistics,

National Transport University, Ukraine
} 
service - Electronic Calculator Environmental Impact Assessment (ECEIA) was developed. The general structure of the Electronic Service includes two main blocks: Block «Database» and Block of calculation, between which there is a direct relationship. Development and implementation of a basic version of a full-featured effective interactive e-service for independent environmental impact assessment according to clearly defined indicators and methods of their assessment contributes to the maximum reduction of the human factor in environmental impact assessment and prevention of possible corruption. When developing the basic version of the Electronic Service, the possibility of further implementation of its additional functions was taken into account, in particular, the possibility of further authorization of users through the use of EDS / QES was provided; expanding the criteria base for environmental impact assessment and technological processes for assessing their impact on the environment; integration of external information into the database of the Electronic Service; tracking and visualization of information on the results of environmental impact assessment of various types of planned activities.

\section{1. Вступ}

3 метою наближення до європейських стандартів, а саме контролю ступеня забруднення навколишнього природного середовища та забезпечення права громадян на безпечне довкілля, у 2017 р. було прийнято Закон України «Про оцінку впливу на довкілля». Необхідність прийняття цього Закону була зумовлена міжнародними зобов'язаннями України, які випливають з Конвенції про доступ до інформації, Конвенції про оцінку впливу на довкілля у транскордонному контексті, Протоколу про приєднання України до Договору про заснування Енергетичного Співтовариства та Угоди про асоціацію між Україною та $€ C$ [1].

Закон визначає, що ОВД необхідна для «планованої діяльності», яка охоплює, серед іншого, будівництво, реконструкцію, технічне переоснащення, розширення, перепрофілювання, ліквідацію (демонтаж) об'єктів, інше втручання у природне середовище [2].

Крім того, був запроваджений Єдиний реєстр з оцінки впливу на довкілля. Інформація, внесена до Єдиного реєстру з оцінки впливу на довкілля, є відкритою [3]. 
Проте, слід зазначити, що розроблюваних заходів щодо наближення законодавства України до нормативно-правової бази СС в контексті оцінки впливу на довкілля було недостатньо. Саме тому в рамках проекту «Консультаційний фонд підтримки асоціації Україна-СС» в Україні федеральною компанією Deutsche Gesellschaft für Internationale Zusammenarbeit (GIZ) GmbH за дорученням Федерального міністерства економічної співпраці та розвитку (BMZ) у травні 2020 року було реалізовано проект з розробки прототипу електронного сервісу оцінки впливу на довкілля ECEIA (ECEIA - electronic calculator environmental impact assessment).

Електронний сервіс дозволяє визначити кількісну оцінку впливу на довкілля планової діяльності суб'єкта господарювання за чітко встановленими показниками та методом їх оцінювання, передбачає обробку та зберігання інформації щодо оцінки впливів на довкілля, яка представлена в звіті з ОВД. Тому його тестування, апробація та подальший девелопмент $є$ актуальними задачами сьогодення.

\section{2. Вплив на довкілля об'сктів транспортно-дорожнього комплексу}

Оцінка впливу автомобілізації на навколишнє середовище повинна враховувати те, що за останні два десятиліття масштаби антропогенної діяльності значно зросли і в окремих регіонах земної кулі вже співвіднесені з величиною природних ресурсів [4].

Забезпечуючи комфортні умови для людини, автомобілізація як категорія суспільного прогресу прямо або побічно, але неминуче негативно впливає на екологічну систему [5].

Залежно від джерела впливу у взаємодії з навколишнім середовищем автодорожній комплекс може змінювати географічний ландшафт, викликати забруднення внаслідок функціонування транспортних засобів, дії спеціалізованого транспорту, від використання засобів проти пилу та ожеледиці, від матеріалів ремонту створювати шумове забруднення (табл. 1).

Спрямованість та характер впливу автомобільної дороги на навколишнє природне середовище залежно від джерел впливу характеризує рис. 1.

При проектуванні автомобільних доріг оцінюванню підлягають усі джерела впливу автомобільної дороги на навколишнє середовище, хоча масштаби їх дії значно відрізняються. 


\section{Вплив автомобільної дороги}

\section{на навколишнс природне середовище}

\begin{tabular}{|l|l|l|}
\hline Джерело впливу & \multicolumn{1}{|c|}{ Спрямованість } & \multicolumn{1}{|c|}{ Характер впливу } \\
\hline $\begin{array}{l}\text { Автомобільна } \\
\text { дорога як } \\
\text { iнженерна } \\
\text { споруда }\end{array}$ & Зміни географічного ландшафту & $\begin{array}{l}\text { Не пов'язаний із } \\
\text { транспортними засобами, } \\
\text { постійний, широкого } \\
\text { охоплення, прямий та } \\
\text { побічний }\end{array}$ \\
\hline Транспортний рух & $\begin{array}{l}\text { Забруднення внаслідок } \\
\text { транспортних викидів. } \\
\text { Шумове забруднення. Пилове } \\
\text { забруднення. Фізична небезпека }\end{array}$ & $\begin{array}{l}\text { Залежно від } \\
\text { iнтенсивності, режимів } \\
\text { руху та складу } \\
\text { транспортного потоку, } \\
\text { постійний, місцевого } \\
\text { охоплення, прямий }\end{array}$ \\
\hline $\begin{array}{l}\text { Технологічн } \\
\text { процеси } \\
\text { будівництва i } \\
\text { реконструкції }\end{array}$ & $\begin{array}{l}\text { Забруднення від викидів } \\
\text { спеціалізованого транспорту, } \\
\text { відходів виробництва, матеріалів } \\
\text { будівництва, будівельного } \\
\text { сміття. Виробничий шум. } \\
\text { Пилове забруднення. Соціальні } \\
\text { незручності. Фізична небезпека }\end{array}$ & $\begin{array}{l}\text { Тимчасовий, } \\
\text { інтенсивний, локальний, } \\
\text { прямий }\end{array}$ \\
\hline $\begin{array}{l}\text { Технологічні } \\
\text { процеси } \\
\text { утримання доріг }\end{array}$ & $\begin{array}{l}\text { Забруднення від використання } \\
\text { засобів проти пилу й ожеледиці. } \\
\text { Забруднення від матеріалів } \\
\text { ремонту. Соціальні незручності } \\
\text { при проведенні ремонтних робіт }\end{array}$ & $\begin{array}{l}\text { Тимчасовий, } \\
\text { малоінтенсивний, } \\
\text { локальний, прямий та } \\
\text { побічний }\end{array}$ \\
\hline
\end{tabular}

Інтереси збереження природи і ландшафту повинні враховуватися на всіх етапах проектування, будівництва й утримання доріг згідно із законодавчими актами, нормативними документами і 3 необхідним дотриманням вимог до технологій.

При цьому необхідно:

1) передбачити шкідливий вплив дороги на природу та ландшафт шляхом необхідного трасування й опорядження доріг;

2) компенсувати неминучий шкідливий вплив на природу та ландшафт заходами охорони природи й ландшафту, щоб після завершення втручання не залишалося значних або стійких негативних наслідків для природного балансу і щоб природний ландшафт був відновлений або заново сформований з контролем відповідних вимог; 


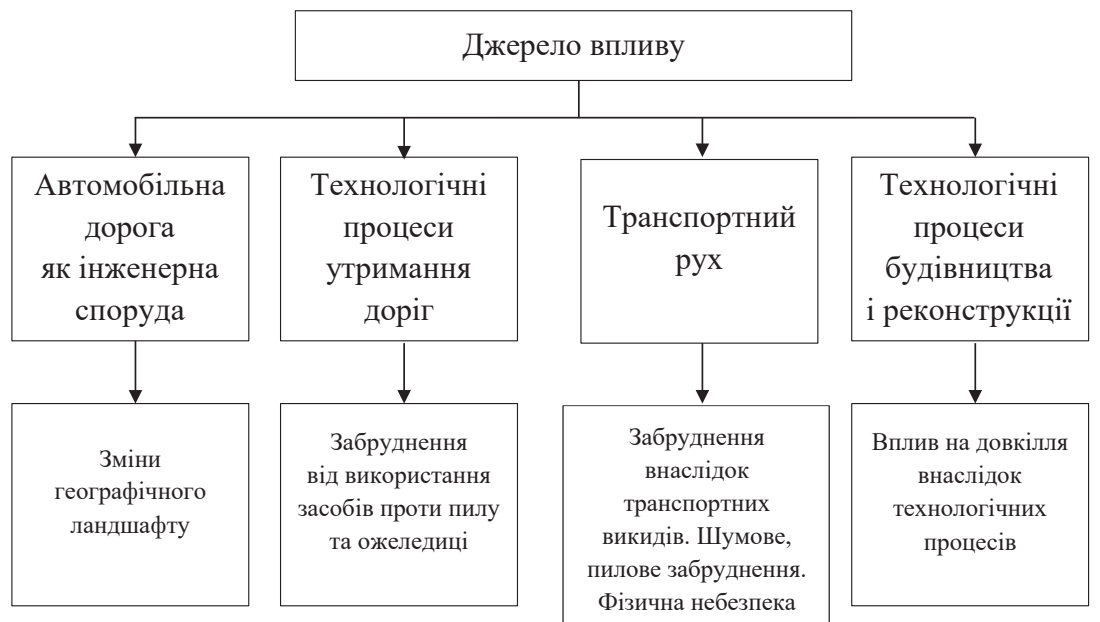

\section{Рис. 1. Вплив автомобільної дороги на навколишнс середовище}

3) підтримувати реалізацію цілей охорони природи та ландшафту в рамках повноважень відповідних дорожніх служб.

За результатами оцінювання екологічного стану існуючої автомобільної дороги й за розрахунками прогнозних рівнів впливу на навколишнє середовище встановлюють екологічний клас автомобільної дороги та виконують порівняльне оцінювання екологічно небезпечних впливів. Характер впливів визначають залежно від спрямованості джерела впливу [6].

Технологічні процеси будівництва і реконструкції та утримання автомобільних доріг мають тимчасовий малоінтенсивний характер та на стан навколишнього середовища суттєво не впливають.

Будівництво та експлуатація автомобільних доріг викликають низку негативних впливів на навколишню природу, тобто на той компонент середовища, який має природний характер. Часом ці впливи опосередковані, виявляються протягом багатьох років у соціальних відносинах і позначаються на здоров'ї людей. До основних негативних впливів автотранспортної комунікації можна віднести знищення природного ландшафту при будівництві дороги, фізичне вилучення частини природного середовища, надання їй антропогенного характеру, втрату 
рослинності, тваринного світу, ерозію грунту, забруднення повітря, води та грунту, порушення балансу поверхні й підземних вод [7].

Оцінивши всі негативні фактори впливу автодорожнього комплексу на навколишнє середовище, можна виокремити принципи проектування автомобільних доріг відповідно до існуючих екологічних норм і вимог (рис. 2).

Тобто зменшення впливу автомобілів на природне середовище та людину можливе за рахунок досконального вивчення проблеми, дотримання екологічних принципів проектування автомобільних доріг, адже від правильності запроектованої автомобільної дороги, врахування екологічних факторів проектування залежить рівень дії транспорту на навколишнє середовище.

Щоб максимально зберегти природний ландшафт при проектуванні та будівництві автомобільної дороги, потрібно дотримуватися головних принципів архітектурно-ландшафтного планування. Вони повинні реалізовуватися вже на стадії планування варіантів траси дороги. Нинішня практика відведення землі, на жаль, незадовільна: перевага майже завжди віддається природним зонам при збереженні земель, зайнятих під промислове або сільськогосподарське виробництво.

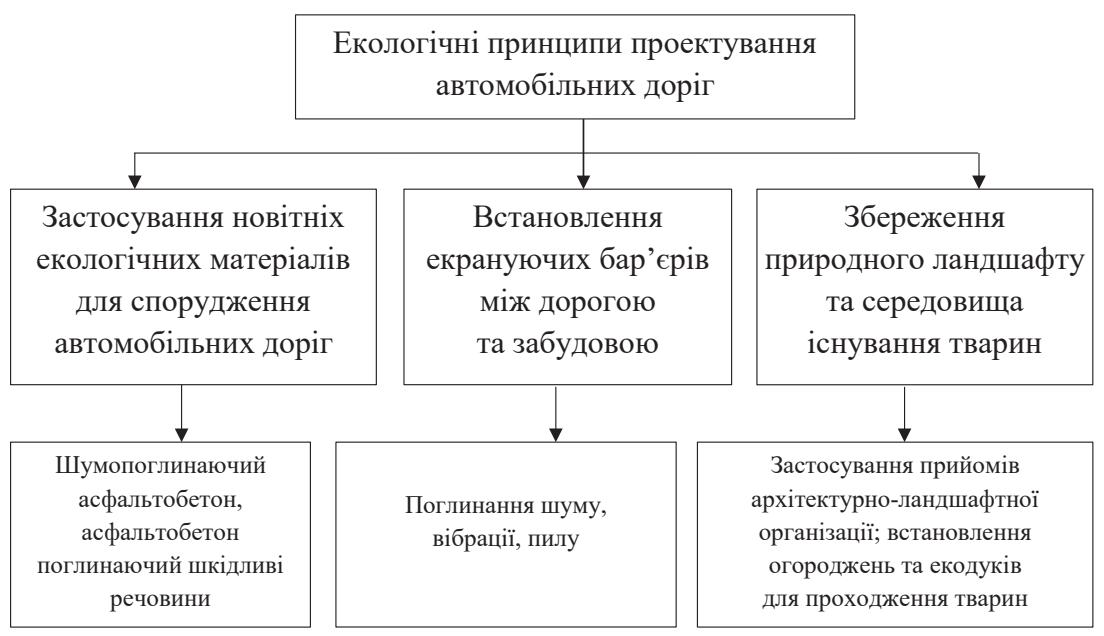

Рис. 2. Екологічні принципи проектування автомобільних доріг 
Проте, слід зазначити, що виявлені принципи екологічного проектування, практичне застосування яких багатофакторним завданням i потребує подальших досліджень.

\section{3. Методи і моделі оцінки впливу на довкілля}

Детальне розуміння всіх процесів ОВД є важливим фактором для досягнення позитивного результату його проведення. Тому важливо комплексно представити всі процеси та визначити їх послідовність та описати при можливості із зазначенням термінів виконання [8].

Процедура оцінки впливу на довкілля складається з 18 етапів які ми розглянемо нижче. Загальна структура етапів ОВД з деталізацією щодо термінів наведено в «Алгоритмі проведення етапів ОВД» на рис. 3.

Eman 1. Підготовка повідомлення про планову діяльність у письмовому та електронному вигляді.

У повідомленні про плановану діяльність, яка підлягає оцінці впливу на довкілля, наводиться інформація про:

1) суб'єкта господарювання - назва (прізвище, ім'я, по батькові), юридична адреса (адреса реєстраціі), контактний номер телефона;

2) плановану діяльність, ії характеристику, технічні альтернативи;

3) місце провадження планованої діяльності, територіальні альтернативи;

4) соціально-економічний вплив планованої діяльності;

5) загальні технічні характеристики, у тому числі параметри планованої діяльності (потужність, довжина, площа, обсяг виробництва тощо);

6) екологічні та інші обмеження планованої діяльності за альтернативами;

7) необхідну еколого-інженерну підготовку і захист території за альтернативами;

8) сферу, джерела та види можливого впливу на довкілля;

9) належність планованої діяльності до першої чи другої категорії видів діяльності та об'єктів, які можуть мати значний вплив на довкілля та підлягають оцінці впливу на довкілля;

10) наявність підстав для здійснення оцінки транскордонного впливу на довкілля;

11) планований обсяг досліджень та рівень деталізації інформації, що підлягає включенню до звіту з оцінки впливу на довкілля; 
Chapter «Engineering sciences»

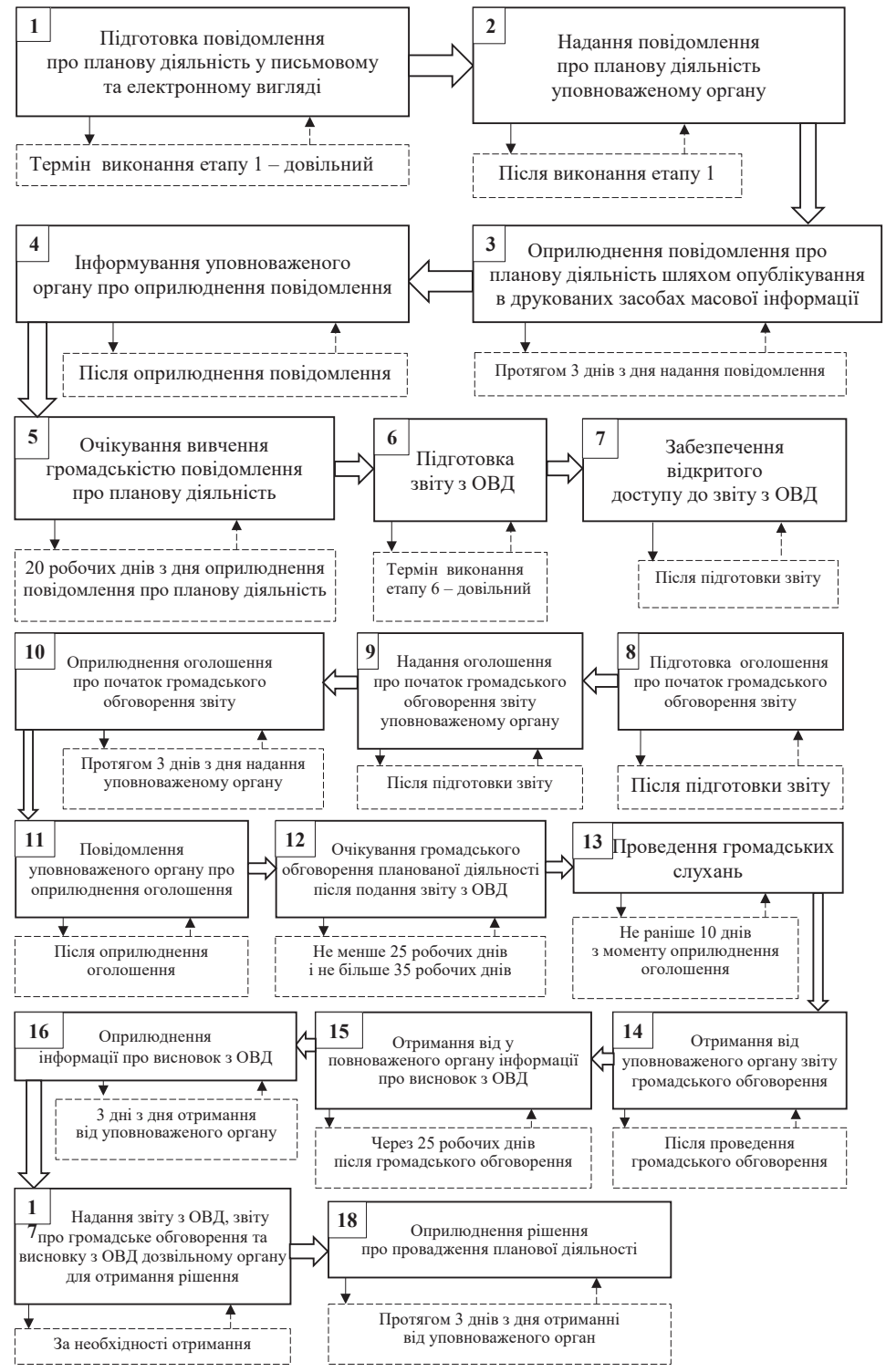

Рис. 3. Алгоритм проведення етапів ОВД 
12) передбачену процедуру оцінки впливу на довкілля та можливості для участі в ній громадськості;

13) проведення та процедуру громадського обговорення обсягу досліджень та рівня деталізації інформації, що підлягає включенню до звіту з оцінки впливу планованої діяльності на довкілля;

14) вид рішення про провадження планованої діяльності, яка підлягає оцінці впливу на довкілля, та орган, до повноважень якого належить прийняття цього рішення;

$15)$ найменування уповноваженого територіального органу.

Eman 2. Надаємо повідомлення про планову діяльність уповноваженому органу через електронний кабінет Єдиного реєстру з оцінки впливу на довкілля (в подальшому може бути використано - «Реєстр», або «електронний кабінет Реєстру»).

Eman 3. Оприлюднення повідомлення про планову діяльність здійснюється шляхом опублікування в друкованих засобах масової інформації (не менше двох), визначених суб'єктом господарювання, територія розповсюдження яких охоплює адміністративно-територіальні одиниці, які можуть зазнати впливу планованої діяльності, а також розміщуються на дошках оголошень органів місцевого самоврядування або в інших громадських місцях на території, де планується провадити плановану діяльність, або оприлюднюються в інший спосіб, що гарантує доведення інформації до відома мешканців відповідної адміністративно-територіальної одиниці, на території якої планується розміщення об'єкта, чи до відповідної територіальної громади, яка може зазнати впливу планованої діяльності, та інших зацікавлених осіб.

Eman 4. Повідомляємо уповноважений орган про оприлюднення повідомлення. Здійснюється після оприлюднення повідомлення.

Eman 5. Очікування вивчення громадськістю повідомлення про планову діяльність. Виконання етапу має бути проведене протягом 20 робочих днів з дня оприлюднення інформації про планову діяльність.

Eman 6. Підготовка звіту з ОВД.

Звіт з оцінки впливу на довкілля включає:

1) опис планованої діяльності, зокрема:

- опис місця провадження планованої діяльності;

- цілі планованої діяльності; 
- опис характеристик діяльності протягом виконання підготовчих і будівельних робіт та провадження планованої діяльності, у тому числі (за потреби) роботи з демонтажу, та потреби (обмеження) у використанні земельних ділянок під час виконання підготовчих і будівельних робіт та провадження планованої діяльності;

- опис основних характеристик планованої діяльності (зокрема виробничих процесів), наприклад, виду і кількості матеріалів та природних ресурсів (води, земель, грунтів, біорізноманіття), які планується використовувати;

- оцінку за видами та кількістю очікуваних відходів, викидів (скидів), забруднення води, повітря, грунту та надр, шумового, вібраційного, світлового, теплового та радіаційного забруднення, а також випромінення, які виникають у результаті виконання підготовчих i будівельних робіт та провадження планованої діяльності;

2) опис виправданих альтернатив (наприклад, географічного та/або технологічного характеру) планованої діяльності, основних причин обрання запропонованого варіанта з урахуванням екологічних наслідків;

3) опис поточного стану довкілля (базовий сценарій) та опис його ймовірної зміни без здійснення планованої діяльності в межах того, наскільки природні зміни від базового сценарію можуть бути оцінені на основі доступної екологічної інформації та наукових знань;

4) опис факторів довкілля, які ймовірно зазнають впливу з боку планованої діяльності та іiі альтернативних варіантів, у тому числі здоров'я населення, стан фауни, флори, біорізноманіття, землі (у тому числі вилучення земельних ділянок), грунтів, води, повітря, кліматичні фактори (у тому числі зміна клімату та викиди парникових газів), матеріальні об'єкти, включаючи архітектурну, археологічну та культурну спадщину, ландшафт, соціально-економічні умови та взаємозв'язки між цими факторами;

5) опис і оцінку можливого впливу на довкілля планованої діяльності, зокрема величини та масштабів такого впливу (площа території та чисельність населення, які можуть зазнати впливу), характеру (за наявності - транскордонного), інтенсивності і складності, ймовірності, очікуваного початку, тривалості, частоти і невідворотності впливу (включаючи прямий і будь-який опосередкований, побічний, кумулятивний, транскордонний, короткостроковий, середньостроковий та 
довгостроковий, постійний і тимчасовий, позитивний і негативний вплив);

6) опис методів прогнозування, що використовувалися для оцінки впливів на довкілля, та припущень, покладених в основу такого прогнозування, а також використовувані дані про стан довкілля;

7) опис передбачених заходів, спрямованих на запобігання, відвернення, уникнення, зменшення, усунення значного негативного впливу на довкілля, у тому числі (за можливості) компенсаційних заходів;

8) опис очікуваного значного негативного впливу діяльності на довкілля, зумовленого вразливістю проекту до ризиків надзвичайних ситуацій, заходів запобігання чи пом'якшення впливу надзвичайних ситуацій на довкілля та заходів реагування на надзвичайні ситуації;

9) визначення усіх труднощів (технічних недоліків, відсутності достатніх технічних засобів або знань), виявлених у процесі підготовки звіту з оцінки впливу на довкілля;

10) усі зауваження і пропозиції, що надійшли до уповноваженого територіального органу, а у випадках, визначених частинами третьою і четвертою статті 5 цього Закону України «Про ОВД» [9], - до уповноваженого центрального органу після оприлюднення ними повідомлення про плановану діяльність, а також таблицю із зазначенням інформації про повне врахування, часткове врахування або обгрунтування відхилення отриманих під час громадського обговорення зауважень та пропозицій;

11) стислий зміст програм моніторингу та контролю щодо впливу на довкілля під час провадження планованої діяльності, а також (за потреби) планів післяпроектного моніторингу;

12) резюме нетехнічного характеру інформації, зазначеної у пунктах 1-11 цієї частини, розраховане на широку аудиторію;

13) список посилань із зазначенням джерел, що використовуються для описів та оцінок, що містяться у звіті з оцінки впливу на довкілля.

Терміни виконання етапу - довільні.

Eman 7. Забезпечення відкритого доступу до звіту з оцінки впливу на довкілля шляхом розміщення у місцях, доступних для громадськості у приміщеннях: уповноваженого органу; органу місцевого самоврядування відповідної адміністративно-територіальної одиниці, яка може зазнати впливу планованої діяльності, суб'єкта господарювання та, 
додатково, може розміщуватися в інших загальнодоступних місцях, визначених суб' єктом господарювання.

Eman 8. Підготовка оголошення про початок громадського обговорення звіту. Даний процес відбувається після підготовки звіту.

Eman 9. Надання оголомення про початок громадського обговорення звіту уповноваженому органу. Дане оголошення подається після підготовки звіту.

Eman 10. Оприлюднення оголошення про початок громадського обговорення звіту у спосіб, вказаний у етапі 3. Даний етап виконують протягом 3 днів 3 дня надання уповноваженому органу.

Eтап 11. Інформування уповноваженого органу про оприлюднення оголошення. Процес здійснюється після оприлюднення оголошення.

Eтап 12. Очікування громадського обговорення планованої діяльності після подання звіту з ОВД. Етап проводиться у формі громадських слухань та у формі надання письмових зауважень і пропозицій (у тому числі в електронному вигляді). Строки виконання не менше 25 робочих днів і не більше 35 робочих днів.

Eman 13. Проведення громадських слухань організатором громадських слухань, визначеного уповноваженим органом, за участю представників підприємства. Здійснюється не раніше десяти днів 3 моменту оприлюднення оголошення.

Eтап 14. Отримання від уповноваженого органу звіту громадського обговорення. Строк виконання - після проведення громадського обговорення.

Eтап 15. Отримання від уповноваженого органу інформації про висновок з ОВД. Дана інформація має надійти до виконавця ОВД протягом 25 днів 3 моменту завершення громадського обговорення.

Eman 16. Оприлюднення інформації про висновок з ОВД у спосіб, вказаний у етапі 3. Дане оприлюднення має бути здійснене не пізніше 3 днів для отримання підтвердження про прийняття рішення про висновок ОВД від уповноваженого органу.

Eтап 17. Надання звіту з оцінки впливу на довкілля, звіту про громадське обговорення та висновку з ОВД дозвільному органу для отримання рішення про провадження планової діяльності (дозвільного документа). Даний етап проводиться якщо виникає необхідність отримання відповідного рішення. 
Етап 18. Оприлюднення рішення про провадження планової діяльності (дозвільного документа) у спосіб, вказаний у етапі 3. Даний етап має бути виконаний протягом 3 днів 3 дня отриманні від уповноваженого органу відповідного дозвільного документу.

Таким чином, дотримання чіткого алгоритму проведення ОВД, $є$ запорукою успішного його проведення. А результатом успішна діяльність підприємства, або будівництво, реконструкція чи експлуатація певних об'єктів.

\section{4. Застосування матриці Леопольда для проведення ОВД}

Для кількісного визначення взаємодії між видами діяльності (або групами діючих факторів) в ході проекту і компонентами (екологічними характеристиками) довкілля застосовується комбінований підхід до оцінки впливу за допомогою удосконаленої матриці Леопольда та його подальше дослідження за допомогою функції Харрінгтона.

На кожному етапі як виконання етапів ОВД так і самих процесів при будівництві та реконструкції (ремонті) автомобільної дороги інформація може бути представлена у вигляді різних матриць. Хоча основний акцент в дослідженні робиться на процеси (ремонту) реконструкції автомобільних доріг в та їх можливий вплив на довкілля, математичний апарат ми будемо розглядати і з точки зору їх будівництва [10].

Матриця є таблицею, яка містить по горизонталі список $з$ процесів, які здійснюють вплив на довкілля, при реконструкції (ремонті) автомобільної дороги, по вертикалі - критерії та показники впливу на довкілля, як характеристики навколишнього середовища.

Шаблон матриці Леопольда для оцінки впливів на навколишнє середовище при будівництві та реконструкції (ремонті) автомобільної дороги приведено на рис. 4.

Оцінювач (аналітик, розробник проекту, експерт) може модифікувати матрицю у відповідності з конкретними завданнями проекту будівництва та реконструкції (ремонту) автомобільної дороги.

Взаємодія між впливами та характеристиками процесу реконструкції (ремонту) автомобільної дороги фіксується у відповідних клітинах матриці, що позволяє виявити, зв'язки у системі. В кожній клітинці матриці може знаходитись одна 3 двох оцінок:

- оцінка, яка відображає інтенсивність впливу (амплітуда); 
Chapter «Engineering sciences»

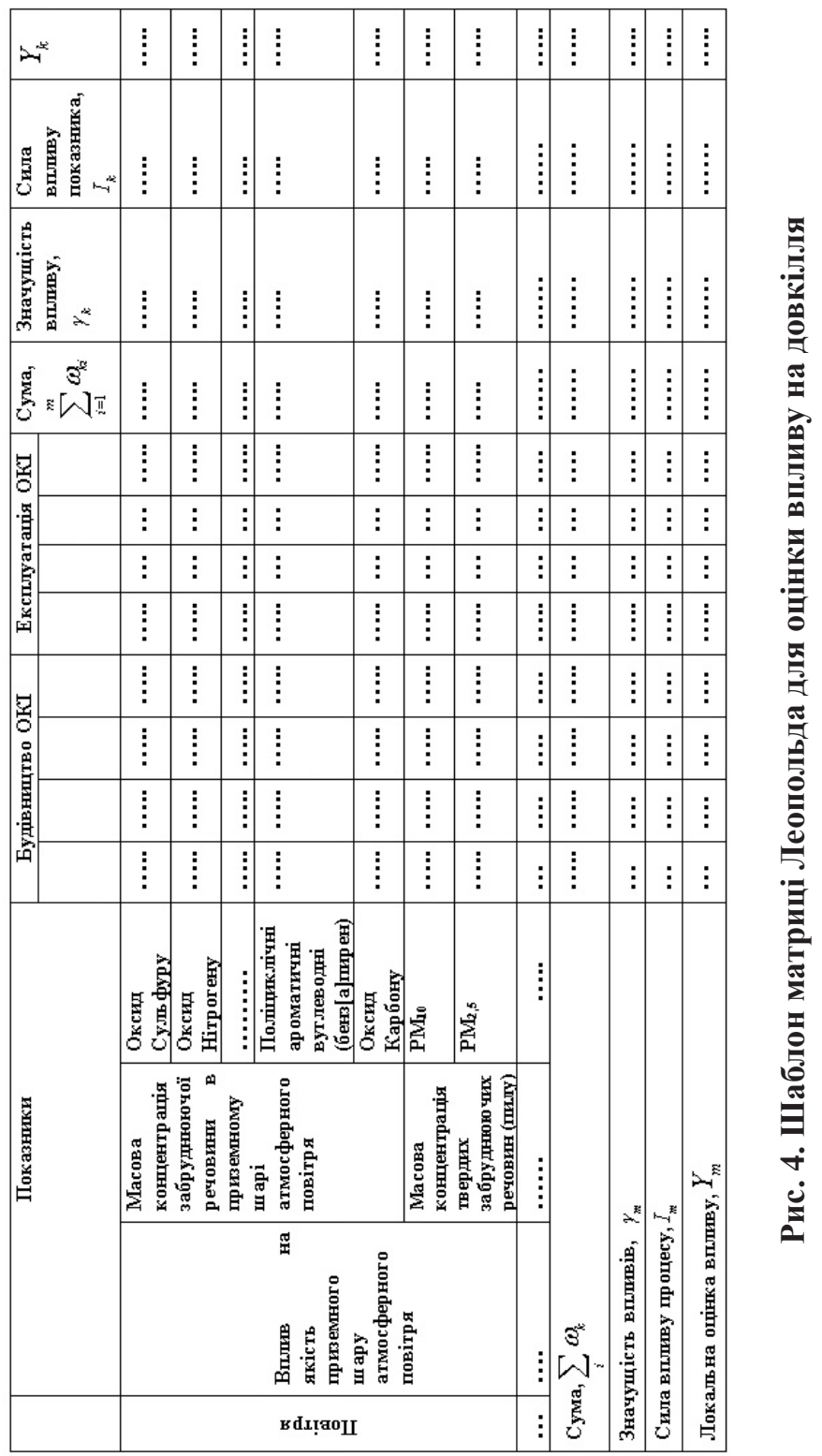




\section{Anna Kharchenko, Ylia Khrutba}

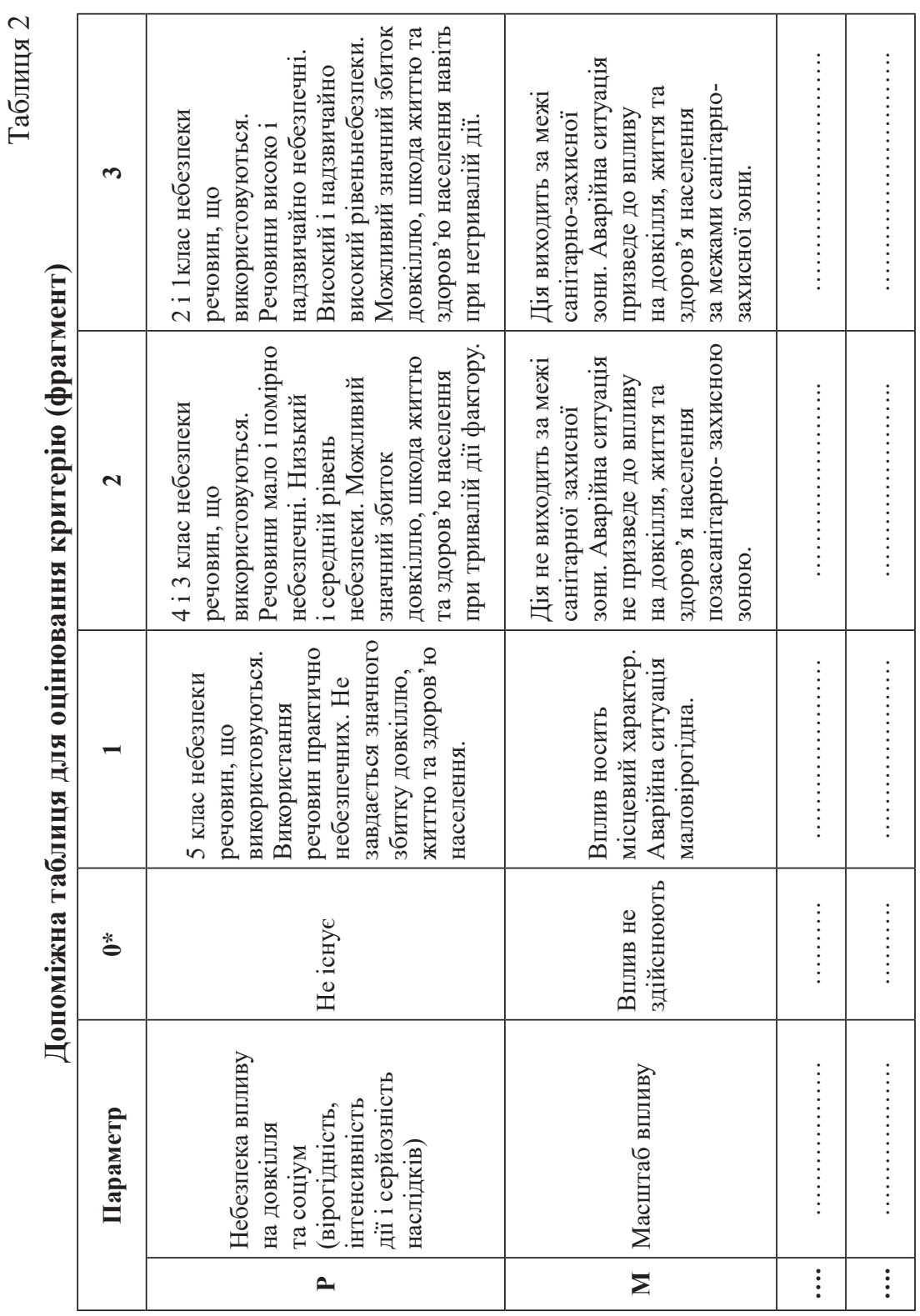


- оцінка, яка є мірою значущзості змін в екосистемі (важливість).

Для визначення кількісної оцінки інтенсивності впливу (амплітуда) значущості змін в екосистемі (важливість), для кожного критерію визначаємо бальну оцінку критерію $\left(\Pi_{\text {оц }}\right)$, за допомогою допоміжної таблиці (табл. 2) [11-13].

Безпосередня бальна оцінка здійснюється за формулою (1):

$$
\Pi_{\text {ou }}=(P+3+C+M+\Phi+T+Y) \times Y,
$$

де $\mathrm{P}$ - оцінка небезпеки впливу;

3 - оцінка виконання законодавчих і нормативно-правових вимог;

С - оцінка громадської думки;

М - оцінка масштабу впливу;

$\Phi$ - оцінка фінансових витрат для подолання наслідків впливу;

Т - використання нових інноваційних технології;

Ч - час або тривалість впливу;

У - оцінка здатності управляти.

Оцінку інтенсивності впливу (амплітуда) та / або значущості змін в екосистемі (важливість), для кожного критерію процесів будівництва та реконструкції (ремонту) автомобільної дороги $\left(\omega_{i}\right)$, які здійснюють вплив на довкілля, визначаємо за табл. 3.

Таблиця 3

Визначення інтенсивності впливу

\begin{tabular}{|c|c|c|}
\hline \multirow{2}{*}{$\begin{array}{c}\text { Підсумкова оцінка } \\
\text { критерію }_{\left(\boldsymbol{\Pi}_{\text {ou }}\right)}\end{array}$} & \multicolumn{2}{|c|}{ Ступінь / інтенсивність впливу } \\
\cline { 2 - 3 } & Значення впливу, $\omega_{i}$ & Категорія впливу \\
\hline $7-13$ & 0 & відсутній \\
\hline $14-24$ & 1 & слабкий \\
\hline $25-35$ & 2 & середній \\
\hline $36-46$ & 3 & сильний \\
\hline $47-57$ & 4 & дуже сильний \\
\hline $58-63$ & 5 & критичний \\
\hline
\end{tabular}

Інтенсивність впливу ( $)$ на об'єкти (характеристики) навколишнього середовища оцінюється в кожній клітині матриці від 0 до 5 за даними табл. 3.

Для аналізу матриці отримані значення підсумовуються по горизонталі і вертикалі $\left(\sum_{i} \omega_{i}\right)$ по окремим показникам та процесам впливу. 
Аналіз результатів дозволяє визначити процеси, які найбільше впливають на довкілля та компоненти навколишнього середовища, які підлягають найбільшому впливу під час будівництва та реконструкції (ремонту) автомобільної дороги.

Максимальні отриманні значення суми балів у стовпцях, при процесах будівництва та реконструкції (ремонту) автомобільної дороги, відповідають найбільш інтенсивним впливам.

Максимальні отриманні значення суми балів у строках відповідають об'єктам (характеристикам) навколишнього середовища, які зазнають максимального впливу.

Після заповнення таблиці розраховується значущість всіх впливів в матриці $(\gamma)$ за формулою:

$$
\gamma=\frac{100}{n}
$$

де $\mathrm{n}$ - кількість значущих клітинок в матриці (в яких $\omega \neq 0$ ).

Загальну силу впливу ( $\left.I_{i}\right)$ визначають за формулою:

$$
I_{i}=\gamma \cdot \sum_{i=1}^{n} \omega_{i} .
$$

У разі застосування у матриці двох оцінок (амплітуди / інтенсивності і важливості/значущості) проводиться ранжування інтенсивного впливу за значимістю змін в екосистемах. При перемноженні ваги впливу і значущості змін за компонентами навколишнього середовища отримують агрегований показник впливу.

Отримані значення підсумовуються по горизонталі і вертикалі матриці. Таким чином визначаються найбільш інтенсивні дії і виявляються об'єкти, які є найбільш чутливими і зазнають найбільшого впливу.

Загальна сила впливу $\left(I_{i}\right)$ у такому випадку знаходиться за формулою:

$$
I_{i}=\frac{\sum_{i=1}^{n} \omega_{i} \cdot \gamma}{s},
$$

де $\mathrm{s}$ - загальна кількість клітин матриці.

Відношення отриманого значення до максимального $I_{\text {мах }}$, виражене у відсотках, визначає ( $\left.Y_{i}\right)$ рівень локального впливу процесу будівництва та реконструкції (ремонту) автомобільної дороги на довкілля або рівень небезпеки для елемента навколишнього середовища. 


$$
Y_{i}=\frac{I_{i}}{I_{\text {мах }}}
$$

Висновок про інтенсивність впливів на навколишнє середовище за варіантами планованої діяльності проводиться шляхом зіставлення аналогічних клітин у матрицях, які відповідають альтернативним варіантам проекту.

Загальну оцінку впливу проекту на довкілля здійснюємо за допомогою функції Харрінгтона.

Зазначена узагальнена функція дозволяє встановити інтегральний показник оцінки впливу на довкілля, який є кількісним, однозначним, універсальним показником якості об'єкта, що досліджується і може використовуватись у якості критерію оцінки впливу при будівництві та реконструкції (ремонті) автомобільної дороги на довкілля через свою адекватність, ефективність та статистичну чутливість.

Для побудови інтегрального показника оцінки впливу на довкілля використовується узагальнена функція бажаності Харрінгтона [14]:

$$
D=\sqrt[m]{\prod_{i=2}^{m} d_{i}}
$$

де $D$ - узагальнена бажаність; $m$ - кількість показників оцінювання стану об'єкту дослідження; $d_{i}$ - частинна бажаність.

Графічне відображення шкали Харрінгтона наведене на рис. 5. Згідно графіку вісь ординат відображає значення бажаності від 0 до 1 ; вісь абсцис - значення показників, що застосовуються при оцінюванні.

Значення показників стандартної шкали бажаності Харрінгтона приведено в табл. 4.

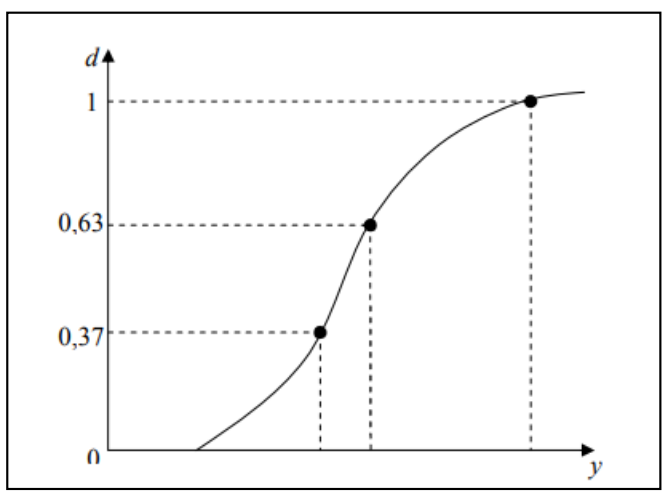

Рис. 5. Стандартна функція бажаності Харрінгтона 
Таблиця 4

\section{Стандартна шкала бажаності Харрінгтона}

\begin{tabular}{|c|c|}
\hline Висновок & Шкала \\
\hline Дуже добре & $1,0-0,81$ \\
\hline Добре & $0,80-0,64$ \\
\hline Задовільно & $0,63-0,38$ \\
\hline Погано & $0,37-0,21$ \\
\hline Дуже погано & $0,20-0$ \\
\hline
\end{tabular}

Інтегральний показник оцінки впливу на довкілля (Y) дорівнює

$$
Y=\sqrt[m]{\prod_{i=2}^{m} Y_{i}}
$$

де $Y_{i}$ - рівень локального впливу процесу реконструкції (ремонті) автомобільної дороги на довкілля; $m$ - кількість локальних показників впливу на довкілля.

Оцінка впливу процесів реконструкції (ремонті) автомобільної дороги на довкілля в безрозмірну шкалу бажаності, яка встановлює відповідність між суб'єктивною оцінкою аналітика та характеристиками об'єкту (значення показників), що досліджується, здійснене на основі функції Харрінгтона, наведено у табл. 5.

Таблиця 5

\section{Градація інтенсивності сили впливу на довкілля процесів} будівництва та реконструкції (ремонту) автомобільної дороги

\begin{tabular}{|l|l|}
\hline $\begin{array}{c}\text { Інтегральний показник } \\
\text { (інтенсивність сили впливу, Y) }\end{array}$ & \multicolumn{1}{|c|}{$\begin{array}{c}\text { Градація інтенсивності } \\
\text { сили впливу }\end{array}$} \\
\hline $0,20-0$ & Дуже (надзвичайно) низький \\
\hline $0,37-0,21$ & Низький \\
\hline $0,63-0,38$ & Задовільний (нижче середнього ) \\
\hline $0,80-0,64$ & Високий \\
\hline $1,0-0,81$ & Дуже високий (надвисокий) \\
\hline
\end{tabular}

Таким чином, чим нижче значення інтегрального показника при будівництві чи реконструкції (ремонті) автомобільної дороги, тим вплив на навколишнє середовище менше і проект буде більш безпечним. 
На рис. 6 представлено алгоритм кількісної оцінки впливу на довкілля 3 використанням матриці Леопольда та функції бажаності Харрінгтона.

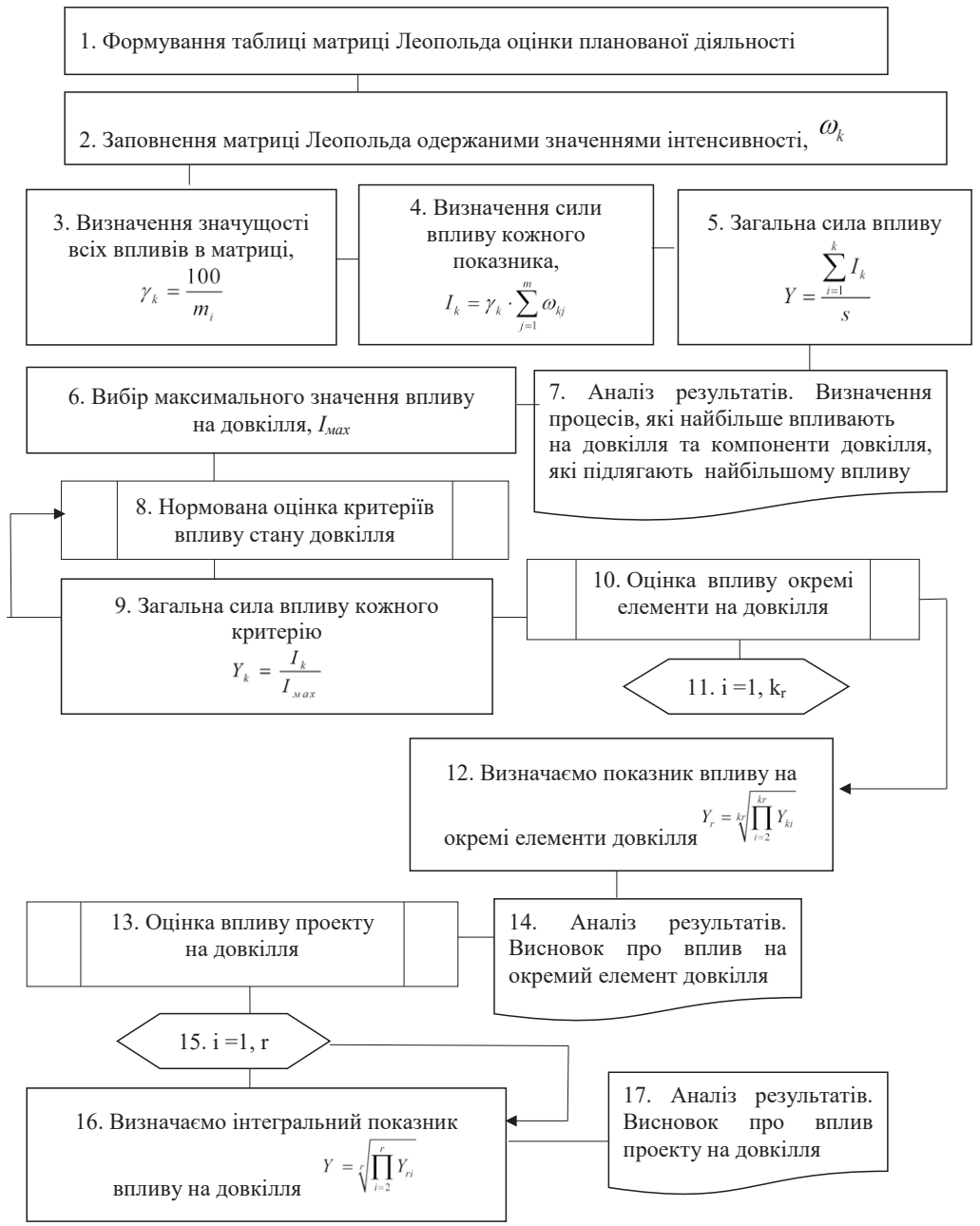

Рис. 6. Алгоритм кількісної оцінки впливу на довкілля 3 використанням матриці Леопольда та функції бажаності Харрінгтона 


\section{5. Розробка та основний функціонал Електронного сервісу}

На основі побудованої методології та алгоритму кількісної оцінки впливу на довкілля 3 використанням матриці Леопольда та функції бажаності Харрінгтона було розроблено електронний сервіс оцінки впливу на довкілля ECEIA (ECEIA - electronic calculator environmental impact assessment).

Загальна структура Блоку Розрахунку Електронного сервісу включає 2 основних блоки: Блок «База даних» та Блок розрахунку, між якими існує безпосередній взаємозв'язок.

Блок «База даних» Електронного сервісу включає такі блоки:

- База Даних «Види планованої діяльності та об'єкти, які можуть мати вплив на довкілля і підлягають оцінці впливу на довкілля». Це сформований Бенефіціаром список видів планованої діяльності та об’єктів, які можуть мати вплив на довкілля і підлягають оцінці впливу відповідно Закону України «Про оцінку впливу на довкілля»;

- База Даних «Основні виробничі процеси, які забезпечують обраний вид планової діяльності». Це сформований Бенефіціаром список виробничих процесів, які забезпечують обраний вид планової діяльності;

- База Даних «Критерії для оцінки впливу на довкілля». Це сформований Бенефіціаром список критеріїв, відповідно ДСТУ Оцінка впливу на довкілля. Транспортні споруди. Критерії оцінки та показники впливів на довкілля.

Загальний вигляд Елекстронного сервісу наведено на рис. 7.

Для виконання розрахунку за новим проектом необхідно натиснути кнопку «Створити новий розрахунок» (рис. 8).

У новому вікні спочатку вводяться усі текстові дані щодо проекту (рис. 9).

Критерії для оцінки впливу на довкілля обираються натисканням кнопки «Вибрати критерії з довідника» (рис. 10).

Довідник критеріїв має ієрархічну структуру, яка має вигляд дерева.

Створений проект має наступний вигляд (рис. 11).

Введення процесів та розрахунок здійснюється 3 окремого довідника (рис. 12).

Блок Розрахунку Електронного сервісу виконує функції:

- розрахунок кількісного значення обраного критерію; 

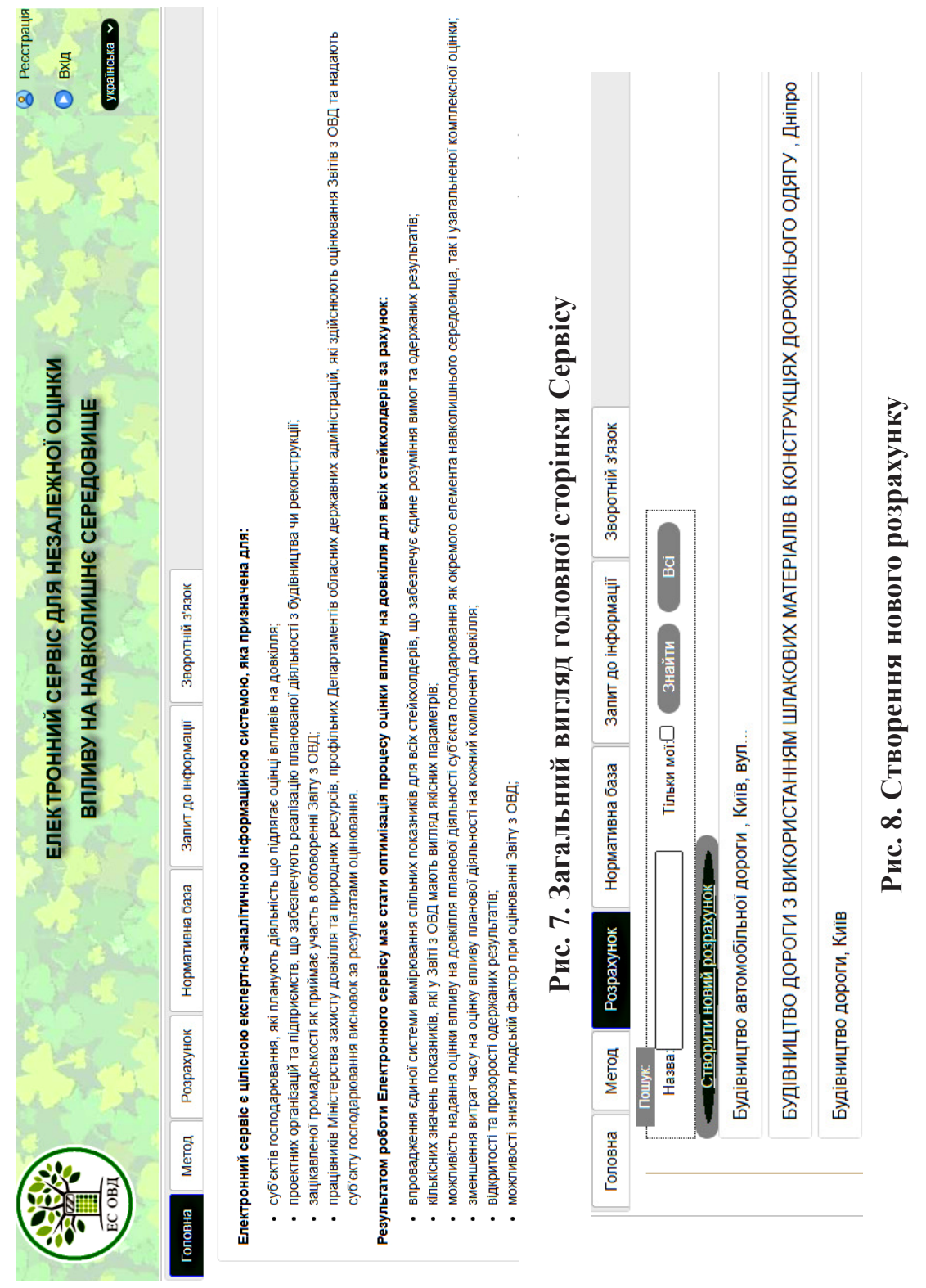

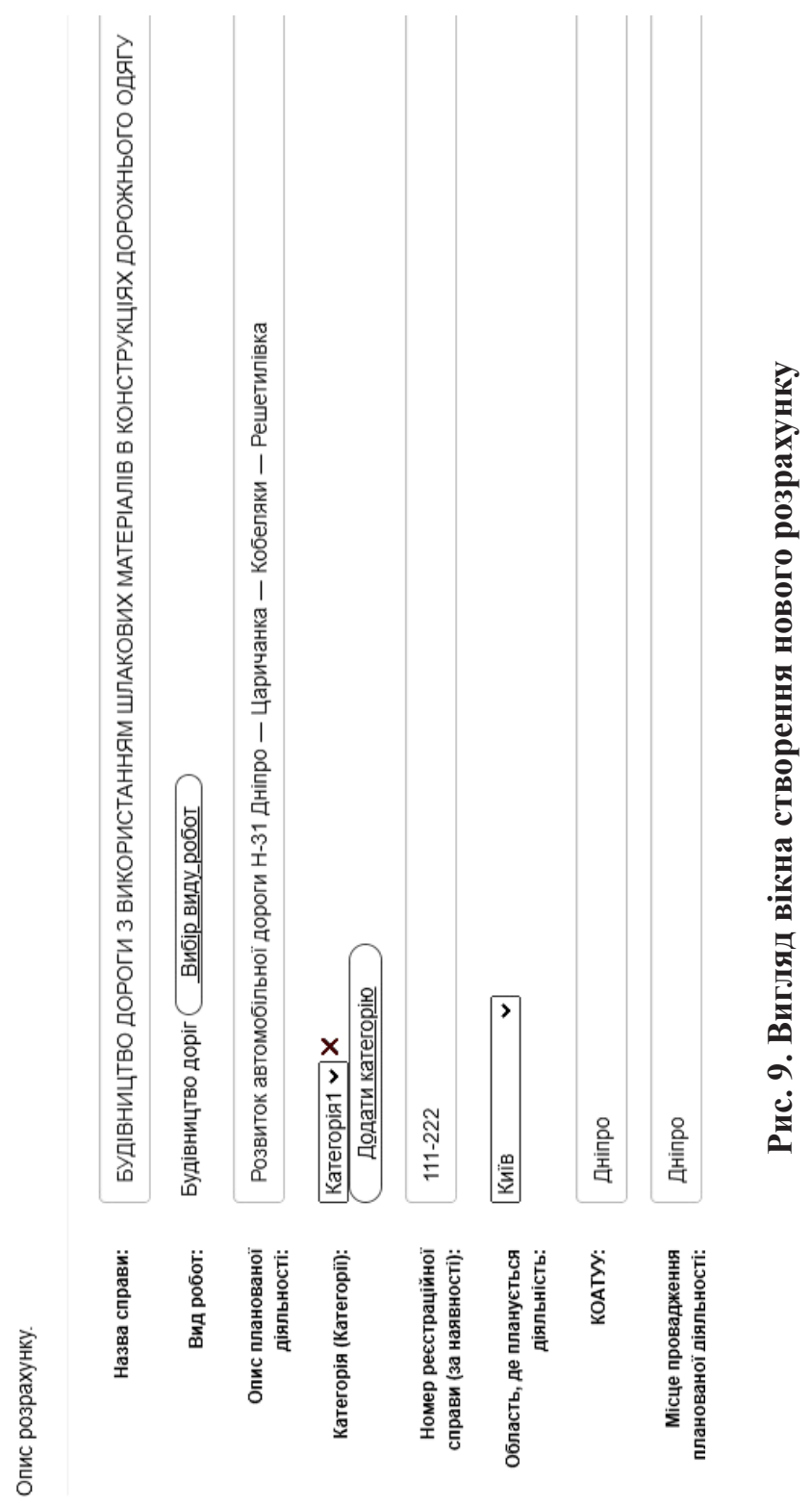


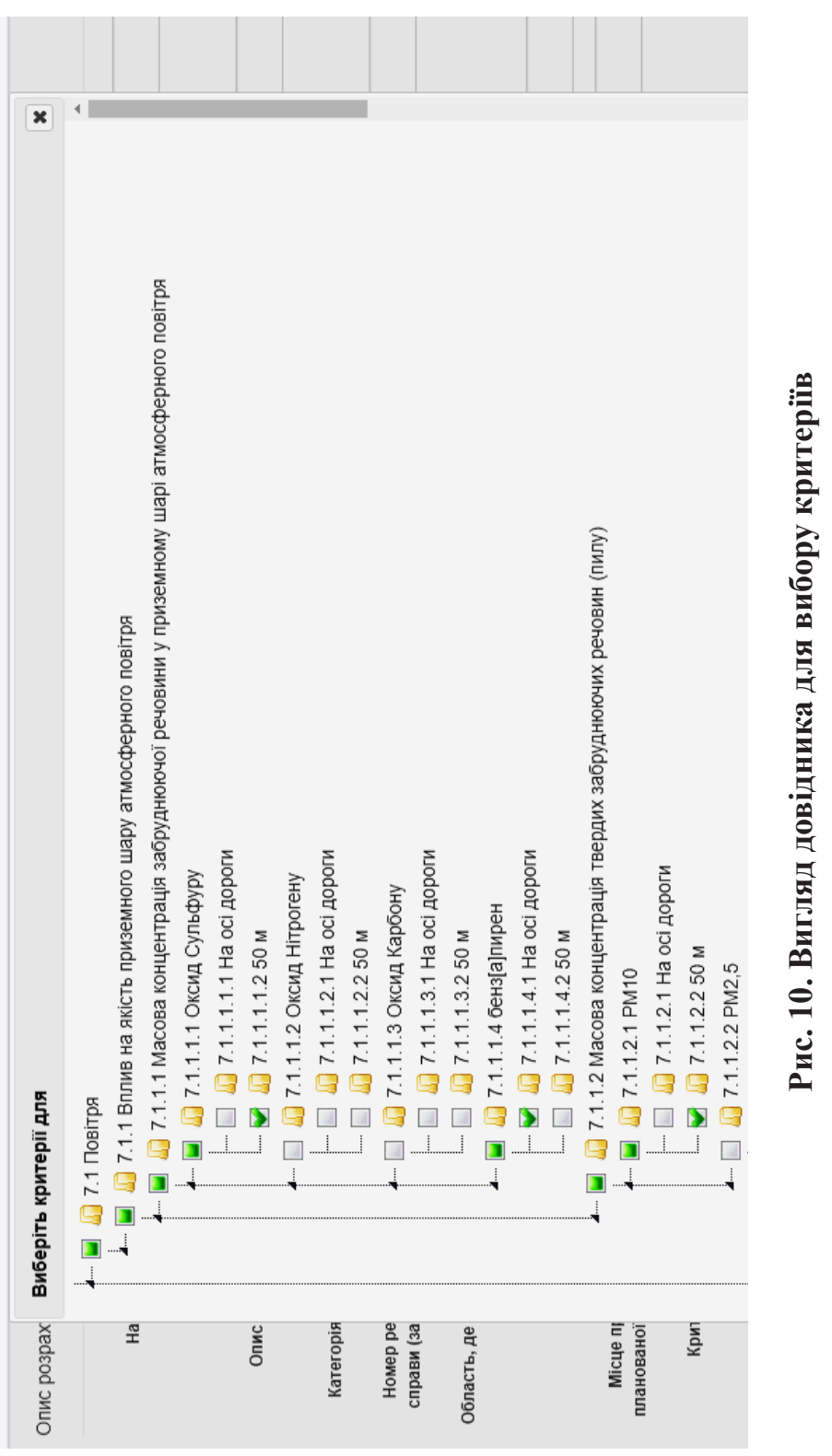




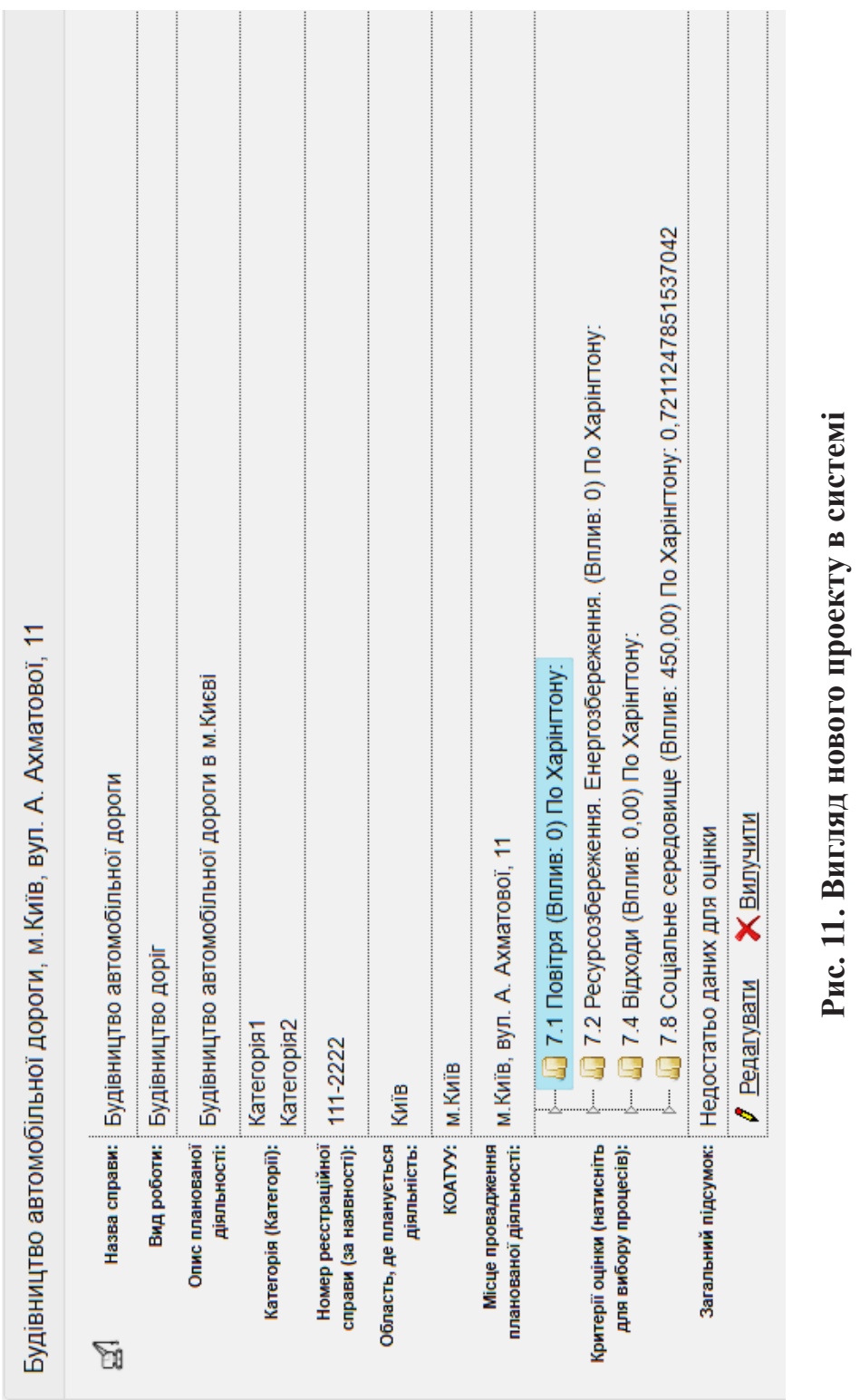



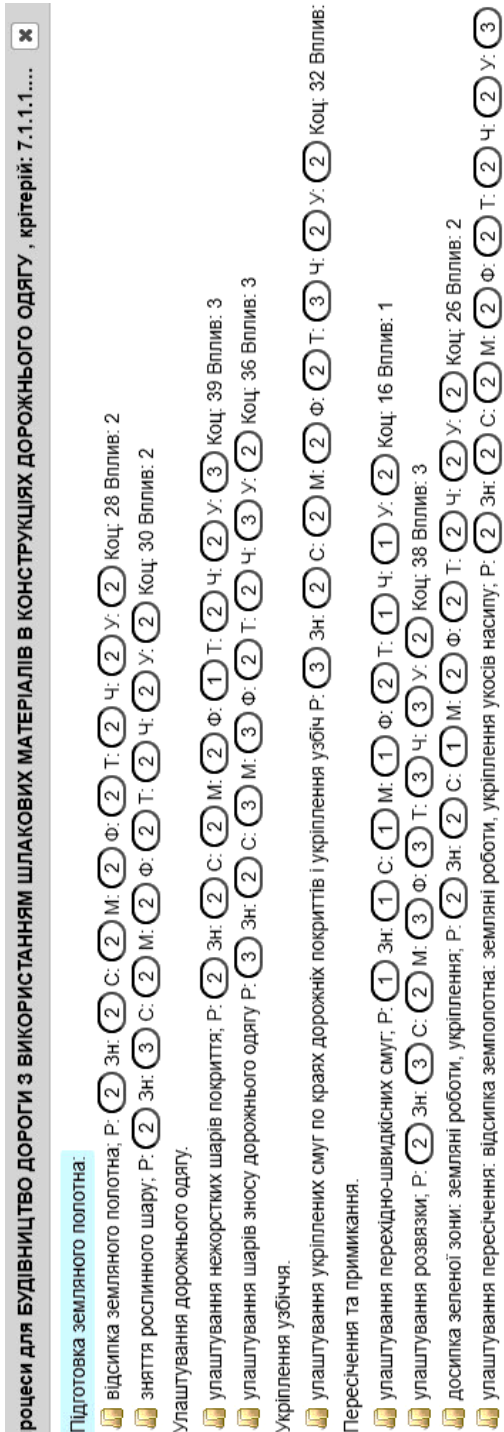

(2) $\quad \stackrel{\circ}{\circ}$

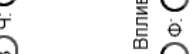

-

() 言 产

○े

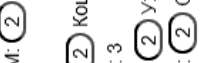

๑)

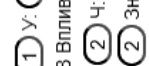

$\bigcup_{i}$

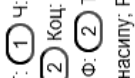

()

คิเั่ง

雨

๑िं

$\Sigma O 0$

๑กิัง

○ค่ิ

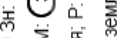

○९̂

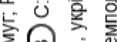

蔺

空至

讨愛

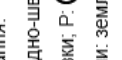

要善产

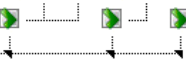

- визначення узагальненого впливу на елементи довкілля процесів, що здійснюють вплив безпосередньо на цей елемент;

- визначення комплексної оцінки впливу на довкілля планової діяльності;

- керування інформаційною структурою;

- керування обміном інформацією зі сторонніми базами даних та комп'ютерними програмами;

- швидко змінювати розрахунок при зміні критеріїв Електронного Сервісу (за потреби).

Блок виводу результатів та прийняття рішень передбачає:

- виведення проміжних результатів у вигляді переліку або таблиці;

- виведення результат впливу по кожному компоненту довкілля;

- виведення результат впливу планової діяльності на довкілля.

Проміжні результати, виводяться після розрахунку критеріїв впливу та представляють у вигляді переліку або таблиці:

- виробничі процеси, які забезпечують обраний вид планової діяльності. 


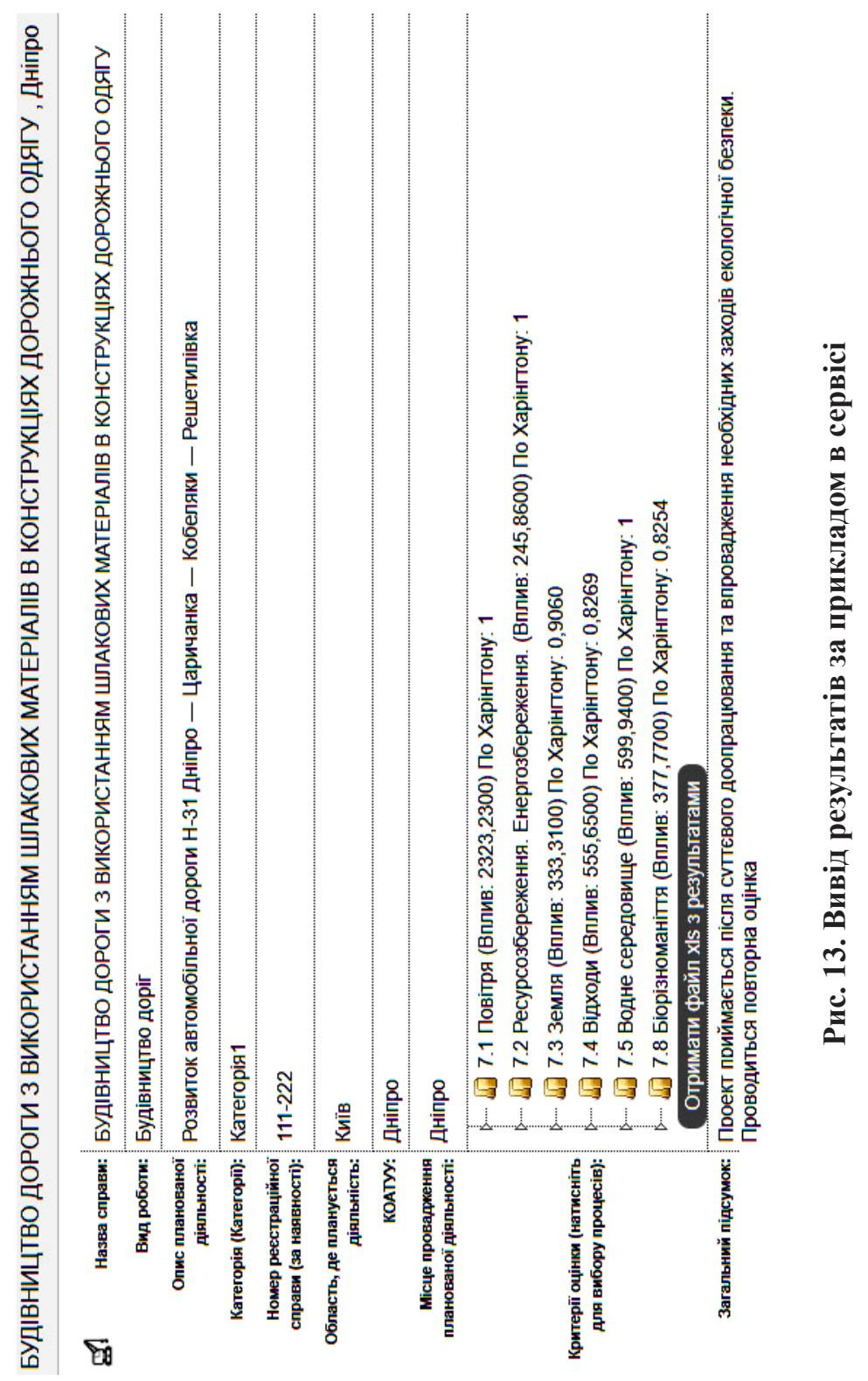


- критерії якості приземного шару атмосферного повітря оцінки впливу з переліком всіх процесів, які здійснюють цей вплив.

Остаточні результати, виводяться після розрахунку впливу по матриці Леопольда (рис. 13) та представляються у вигляді відповідних таблиць, зашитих в оболонку сервісу:

- кількісного результату впливу по кожному компоненту довкілля;

- кількісного результату впливу планової діяльності на довкілля.

Результатом розробки є новий, повноцінний інформаційний портал з сучасним дизайном і функціоналом для різних категорій користувачів, що відповідає сучасним тенденціям і вимогам до сайтів державних органів. Сервіс орієнтований на подачу інформації, зручність використання і дизайн.

Цільова аудиторія сервісу визначається такими категоріями:

- суб'єкти господарювання, які планують діяльність що підлягає оцінці впливів на довкілля;

- проектні організації та підприємства, що забезпечують реалізацію планованої діяльності з будівництва чи реконструкції;

- представники зацікавленої громадськості, які приймають участь в обговоренні Звіту з ОВД;

- працівники Міністерства захисту довкілля та природних ресурсів, профільних Департаментів обласних державних адміністрацій, які здійснюють оцінювання Звітів з ОВД та надають суб'єкту господарювання висновок за результатами оцінювання.

\section{6. Висновки}

Під час дослідження визначено, що оцінка впливу на довкілля $є$ правовим інструментом попередження шкідливих екологічних наслідків, більш сучасним та наближеним до європейських стандартів. Важливим $є$ те, що ОВД здійснюється ще до початку реалізації будь-якого проекту, а не на етапі його затвердження. Шляхом створення електронного реєстру ОВД було спрощено процедуру подання документів.

Водночас, незважаючи на те, що запровадження нової процедури ОВД покликано замінити морально застарілі інструменти, а також зробити процес оцінки впливу на довкілля більш прозорим та ефективним, кількість етапів отримання висновку з ОВД робить цю процедуру складною і надто тривалою, що не може не мати негативний вплив на бізнес. 
Розробка та впровадження базової версії повнофункціонального дієвого інтерактивного Електронного сервісу для незалежної оцінки впливів на довкілля за чітко встановленими показниками та методом їх оцінювання сприяє максимальному зниженню людського фактору при оцінюванні впливів на довкілля та запобіганню можливим корупційним проявам.

Завдання, які вирішує пропонований Електронний Сервіс:

- впроваджує єдину уніфіковану систему вимірювання спільних показників для всіх стейкхолдерів, що забезпечує єдине розуміння вимог та одержаних результатів;

- забезпечує повний і зручний доступ до розрахунку кількісних значень показників, які у Звіті з ОВД представлено у вигляді якісних параметрів;

- надає суб'єктам господарювання, які планують діяльність що підлягає оцінці впливів на довкілля, визначити кількісні показники впливу на довкілля на стадії підготовки Звіту з ОВД;

- надає відповідним структурам Міністерства захисту довкілля та природних ресурсів, профільних Департаментів обласних державних адміністрацій, які здійснюють оцінювання Звітів з ОВД інформацію про кількісні показники впливу на довкілля в поданих Звітах, для надання суб'єкту господарювання висновку за результатами оцінювання;

- надає представникам зацікавленої громадськості, які приймають участь в обговоренні Звіту з ОВД, повну, структуровану та точну інформацію про рівні впливу на окремі елементи навколишнє середовище та узагальнену комплексну оцінку впливу запланованої діяльності на довкілля;

- зменшує витрати часу на оцінку впливу планової діяльності на кожний компонент довкілля;

- забезпечує можливість збереження інформації та аналіз одержаних результатів в особистому електронному кабінеті;

- забезпечує відкритість та прозорість одержаних результатів , можливість знизити людській фактор при оцінюванні впливів на довкілля для запобігання можливим корупційним проявам.

Розробляючи базову версію Електронного Сервісу, було врахувано можливість подальшої реалізації його додаткових функцій, зокрема, передбачено можливість: 
- подальшої авторизації користувачів через використання ЕЦП/КЕП;

- розширення критеріальної бази оцінки впливу на довкілля;

- розширення бази даних технологічних процесів для здійснення оцінки їх впливу на довкілля;

- інтеграції зовнішньої інформації до бази даних Електронного Сервісу;

- відстеження та візуалізація інформації щодо результатів оцінки впливу на довкілля різних видів планової діяльності.

\section{Список літератури:}

1. Наближення екологічного законодавства до права ЄС. Видання Європейського Союзу. Київ, 2017. URL: https://menr.gov.ua/news/31440.html

2. Ольга Науменко. Оцінка впливу на довкілля vs Екологічна експертиза. Юридична газета Online, 2018. URL: http://yur-gazeta.com/publications/practice/ inshe/ocinka-vplivu-na-dovkillya-vs-ekologichna-ekspertiza-shcho-zminilosya.html

3. В Україні з'явиться Єдиний реєстр із оцінки впливу на довкілля. Київ, 2018. URL: https://menr.gov.ua/news/31928.html

4. Транспортна екологія : Навчальний посібник / O.I. Запорожець, С.В. Бойченко, О.Л. Матвєєва, С.Й. Шаманський, Т.І. Дмитруха, С.М. Маджд; за заг. редакцією С.В. Бойченка. Київ : «Центр учбової літератури», 2017. 508 с.

5. ДБН А.2.2-1-2003. Склад і зміст матеріалів оцінки впливів на навколишне середовище. Київ : Держбуд України, 2003. 73 с.

6. ДБН В.2.3-4:2007. Споруди транспорту. Автомобільні дороги. Київ : Держбуд України, 2007. 84 с.

7. Хрутьба В.О., Вайганг Г.О., Зюзюн В.І. Результати екологічної та соціальної оцінки проектів будівництва та реконструкції доріг. Науково-технічний збірник «Восточно-европейский журнал передовых технологий». 2015. № 4/10 (76). С. $26-34$.

8. Алгоритм дій для підприємства в межах Закону України «Про оцінку впливу на довкілля». 2018. URL: http://ecolog-ua.com/articles/algorytm-diydlya-pidpryyemstva-v-mezhah-zakonu-ukrayiny-pro-ocinku-vplyvu-na-dovkillya

9. Про оцінку впливу на довкілля : Закон України від 23 травня 2017 року № 2059-VIII. Офіційний портал Верховної Ради України. URL: http://zakon2.rada.gov.ua/laws/show/2059-19

10. Leopold L.B. A procedure for evoluting environmental impact / L.B. Leopold, F.E. Clarke, B.B. Hanshaw and others. Washington, 1971. 13 p.

11. Руденко С.В., Олех Т.М., Гогунский В.Д. Модель обобщенной оценки воздействия на окружающую среду в проектах. Управління розвитком складних систем. 2013. № 15. С. 53-60.

12. Олех Т.М., Колесникова Е.В., Руденко С.В. Экологическая оценка проектов. Праці Одеського політехнічного університету. 2013. Вип. 2(41). C. 276-282. 
13. Олех Т.М. Розробка моделей цілепокладання та методів прийняття рішень в проектах на основі багатовимірних оцінок : дис... на здоб. канд. техн. наук. Одеський національний політехнічний університет. Одеса, 2015. 174 с.

14. Ахназарова С.Л., Гордеев Л.С. Использование функции желательности Харрингтона при решении оптимизационных задач химической технологии : Учебно-методическое пособие. Москва : РХТУ им. Д.С. Менделеева, 2003. 76 с.

\section{References:}

1. Nablyzhennja ekologhichnogho zakonodavstva do prava JeS. (2016). Vydannia Yevropeiskoho Soiuzu. Kyiv. URL: https://menr.gov.ua/news/31440.html

2. Olha Naumenko. Otsinka vplyvu na dovkillia vs Ekolohichna ekspertyza. (2018). Yurydychna hazeta Online. URL: http://yur-gazeta.com/publications/practice/ inshe/ocinka-vplivu-na-dovkillya-vs-ekologichna-ekspertiza-shcho-zminilosya.html

3. V Ukrajini z'javytjsja Jedynyj rejestr iz ocinky vplyvu na dovkillja (2018). Kyiv. URL: https://menr.gov.ua/news/31928.html

4. Zaporozhecj, O.I., Bojchenko, S.V., Matvjejeva, O.L., Shamansjkyj, S.J., Dmytrukha, T.I., Madzhd, S.M. (2017). Transportna ekologhija: navchaljnyj posibnyk. Kyiv: «Centr uchbovoji literatury», $508 \mathrm{~s}$.

5. DBN A.2.2-1-2003. Sklad i zmist materialiv ocinky vplyviv na navkolyshnje seredovyshhe. (2003). Kyiv: Derzhbud Ukrajiny, 73 s.

6. DBN V.2.3-4:2007. Sporudy transportu. Avtomobiljni doroghy (2007). Kyiv: Derzhbud Ukrajiny, $84 \mathrm{~s}$.

7. Khrutjba, V.O. and others (2015). Rezuljtaty ekologhichnoji ta socialjnoji ocinky proektiv budivnyctva ta rekonstrukciji dorigh. Naukovo-tekhnichnyj zbirnyk «Vostochno-evropejskyj zhurnal peredovblkh tekhnologhyj», no. 4/10 (76), pp. 26-34.

8. Alghorytm dij dlja pidpryjemstva v mezhakh Zakonu Ukrajiny «Pro ocinku vplyvu na dovkillja» (2018). URL: http://ecolog-ua.com/articles/algorytm-diydlya-pidpryyemstva-v-mezhah-zakonu-ukrayiny-pro-ocinku-vplyvu-na-dovkillya

9. Pro ocinku vplyvu na dovkillja: Zakon Ukrajiny (2017). Oficijnyj portal Verkhovnoji Rady Ukrajiny, № 2059-VIII. URL: http://zakon2.rada.gov.ua/laws/ show/2059-19

10. Leopold, L.B. and others (1971). A procedure for evoluting environmental impact. Washington, $13 \mathrm{p}$.

11. Rudenko, S.V. (2013). Modelj obobshhennoj ocenky vozdejstvyja na okruzhajushhuju sredu v proektakh. Upravlinnja rozvytkom skladnykh system, no. 15, pp. 53-60.

12. Olekh, T.M. (2013). Ekologhycheskaja ocenka proektov. Praci Odesjkogho politekhnichnogho universytetu, vol. 2(41), pp. 276-282.

13. Olekh, T.M. (2015). Rozrobka modelej cilepokladannja ta metodiv pryjnjattja rishenj v proektakh na osnovi baghatovymirnykh ocinok: dys. ... na zdob. kand. tekhn. nauk. Odesjkyj nacionaljnyj politekhnichnyj universytet. Odesa, 174 p.

14. Akhnazarova, S.L. (2003). Yspoljzovanye funkcyy zhelateljnosty Kharrynghtona pry reshenyy optymyzacyonnykh zadach khymycheskoj tekhnologhyy: Uchebno-metodycheskoe posobye. Moskva: RKhTU ym. D.S. Mendeleeva, 76 s. 